inOedia $\quad \begin{aligned} & \text { InMedia } \\ & \text { The French Journal of Media Studies }\end{aligned}$

7.1. $\mid 2018$

Visualizing Consumer Culture

Casey Ryan Kelly, Abstinence Cinema: Virginity and
the Rhetoric of Sexual Purity in Contemporary Film

New Brunswick: Rutgers University Press, 2016

Benjamin Campion

(2) OpenEdition

Journals

Electronic version

URL: http://journals.openedition.org/inmedia/1313

DOI: 10.4000/inmedia.1313

ISSN: 2259-4728

Publisher

Center for Research on the English-Speaking World (CREW)

Electronic reference

Benjamin Campion, « Casey Ryan Kelly, Abstinence Cinema: Virginity and the Rhetoric of Sexual Purity in Contemporary Film », InMedia [Online], 7.1. | 2018, Online since 20 December 2018, connection on 23 September 2020. URL : http://journals.openedition.org/inmedia/1313 ; DOI : https://doi.org/ 10.4000/inmedia.1313

This text was automatically generated on 23 September 2020

(C) InMedia 


\section{Casey Ryan Kelly, Abstinence Cinema: Virginity and the Rhetoric of Sexual Purity in Contemporary Film}

New Brunswick: Rutgers University Press, 2016

Benjamin Campion

\section{REFERENCES}

Casey Ryan Kelly, Abstinence Cinema: Virginity and the Rhetoric of Sexual Purity in Contemporary Film, New Brunswick: Rutgers University Press, 2016

1 In an era of "pornification", of "pornographic culture" and of what appears to be an irremediable "mainstreaming of pornography", Casey Ryan Kelly's Abstinence Cinema should be commended for its willingness to provide a singular perspective on contemporary popular cinema. Indeed, drawing on his expertise as an associate professor of critical communication and media studies at Butler University (Indianapolis), Kelly has decided to focus his efforts exclusively on Hollywood films produced since 2000: the Twilight Saga (2008-2012, chapter 1), The 40-Year-Old Virgin (2005, chapter 2), The Possession (2012, chapter 3), Taken (2008, chapter 4), and a mix of sexploitation satires from Easy A (2010) to 18-Year-Old Virgin (2012, chapter 5). Teen melodrama, romance, comedy, horror, action-adventure, suspense thriller: he explores a wide spectrum of genres through films more or less focused on virginity, purity and teen sexuality.

2 Heavily documented, his essay relies mainly on two (not so far away) rhetorics: the evangelical movement's abstinence-only "dogma”, and the postfeminist praise of choice and empowerment in a world still largely dominated by men. That's why you'll find in this book a great mix of key expressions like "have it all", "losing control", "true 
love waits", "secondary virginity", "purity movement", "Victorian true womanhood", "moral panic", "monstrous feminine", and "virgin/whore binary", each time used as a predefined tool for Kelly to express his own point of view. Here's where this work reveals itself a little bit frustrating: in its inability to find its own voice and to formulate fresh, strong and unexpected hypotheses. That Hollywood so-called "liberated" sexoriented films may turn out to be more conservative and anti-feminist than was thought in the first place is old news; besides, by analyzing a new set of counternarratives in his conclusion - or final "chapter", as he names it -, Kelly seems to be looking for answers to his own inquiries as much as opening up new research avenues for future works.

3 Another of this study's obvious limitations is its (self-assumed) critical rhetorical approach. As a matter of fact, viewing films as strictly "social texts" that negotiate the status of virginity in American culture leads Kelly to obliterate any aesthetic or, at least, visual consideration. As he states himself: "Approached as a species of symbolic action, the rhetoric of film is less about film aesthetics and form than it is about how a film 'makes sense' in a particular cultural context through a combination of plot, narrative causality, dialogue, characterization, and mise-en-scène" (19). The danger of such a textual perspective is that it drives the author to simply "repeat" what pictures have to say, at the risk of undercutting his own way of thinking. Worse, Kelly often seems to have no other choice than echoing what has already been claimed by theorists, activists and evangelists with no cinema (nor media) expertise. For instance, trying to make sense of The 40-Year-Old Virgin's phallocentric ideology and perception of the liberated woman as a sexual threat, Kelly seems compelled to defend himself: "Without providing a totalizing psychoanalytical interpretation..." (65), he writes, as a way to paraphrase previous well-known statements while maintaining a safety distance with potentially surinterpretative thoughts. "Despite [Stephenie] Meyer's best efforts to depoliticize the series..." (30), "Although the Twilight saga offers a romantic embrace of the cult of true womanhood..." (40), "While it is unlikely that it was the intention of the filmmakers..." (67), "While possession films and purity culture may not share an apparent connection..." (77), "While it is of course true that films should not be critiqued merely for their lack of verisimilitude..." (101): many times, Kelly blatantly feels the need to carry a white flag as a way to protect himself from criticisms to come. As if he were not convinced himself by what he was about to put into black and white letters.

4 Yet, his textual analyses deserve a full consideration for their precision and their ability to highlight America's ongoing and still unsolved cultural debates over sexuality. Defining abstinence cinema as "an emerging constellation of disparate film texts from 2000 to the present day that [...] represent virginity and sexual purity in ways that prioritize both the utopian and dystopian visions of pro-abstinence discourse" (5-6), Kelly is constantly looking for a truth that will, in the end, prove to be far more complex and ambiguous than expected. For instance, one could perceive the horror film Possession as an accommodating allegory of youth perversion and female depravation, but as demonstrates Kelly in his third chapter, it rather "reasserts traditional family values as the solution to the 'demons' of a secular, permissive, and sex-saturated culture" (82). In other words, the author doesn't deny a highly discussed and studied "pornification" of western modern society, but, at the same time, he strives to remind us that American popular culture in general (and Hollywood cinema in particular) remains a very efficient and persuasive conservative "tool" seeking to 
demonize sexuality and to curtail female sexual agency - even when it depicts halfnaked teenagers' sex-quests or immature adults' desperate efforts to lose their virginity...

5 That brings me to express one last (but not least) regret: that Kelly have to wait for his conclusion to step into the arena and assert loudly and clearly what was implied all along. "Because of its emphasis on the physical and moral danger posed by female sexuality - and the fact that it pays little to no attention to young men - abstinence rhetoric translates systemic cultural misogyny into a social and religious imperative to control women's bodies" (129), he finally writes towards the end of his essay. Sadly, what would have constituted a great starting point confines itself to a mere - yet essential - reminder of Hollywood's still (and more than ever?) influential conservative, patriarchal and misogynistic values. There undoubtedly is a promise of a "post-yet-not-dead-Weinstein-era" analysis inside Kelly's 2006 Abstinence Cinema; I would love to read that one, for sure.

6 To conclude, Kelly's work must be hailed for its determination not to fall into the trap of unilateral, opportunistic and self-gratifying "sex is everywhere" discourses - often a falsely intellectualized way of drawing readers' attention by means of indecent material. Abstinence Cinema also has the advantage of avoiding an all too common "politique des auteurs" approach that would once again contribute to put aside Hollywood's most popular and (therefore) influential films from a great deal of contemporary cultural studies. Actually, despite some significant flaws I mentioned earlier, this book may well enlighten you in terms of what price one have to pay in order to conform to a so-called "liberated" postmodern society, revealing itself a truly relevant indicator of Hollywood's deeply rooted yet far from obsolete evangelical moral and political values. That's already quite an achievement.

\section{AUTHORS}

\section{BENJAMIN CAMPION}

Université Le Havre Normandie 